
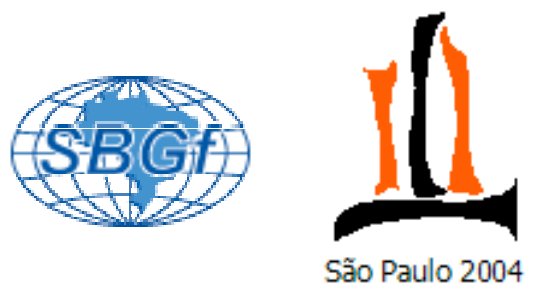

\title{
Diagnóstico da contaminação hídrica subterrânea e superficial provocada por resíduos sólidos urbanos e de curtume, no município de Alagoinhas, BA.
}

\author{
Patrícia de Andrade Pereira, IG/UFBA; Maria José M. do Rêgo, IG/UFBA e Olivar A. L. de Lima, CPGG/UFBA
}

Copyright 2004, SBGf - Sociedade Brasileira de Geofísica

Este texto foi preparado para a apresentação no I Simpósio de Geofísica da Sociedade Brasileira de Geofísica, São Paulo, 26-28 de setembro de 2004. Seu conteúdo foi revisado pela Comissão Tecno-científica do I SR-SBGf mas não necercariamente representa a opinião de SBGf ou de seus associados. E proibida necessariamente representa a opiniáo da SBGf ou de seus associados. E proibida a parcial deste material para propósitos comerciais sem prévia autorização da SBGf.

\section{Resumo}

Contaminações hídricas estão sendo associadas à presença de um antigo lixão, aos resíduos de um curtume, e ao atual aterro sanitário municipal. Para tal caracterização utilizou-se geofísica elétrica em conjunto com análises físico-químicas e bacteriológicas de águas. Resultados de 49 SEVs delinearam uma anomalia condutiva tridimensional, que se estende desde $5 \mathrm{~m}$ a mais de $40 \mathrm{~m}$ de profundidade. Esta é interpretada como resultante da invasão de líquidos originados do lixão e lagoas residuais do curtume. Análises de águas superficial e subterrânea evidenciam a contaminação superficial, com alterações sensíveis nas concentrações de $\mathrm{Cr}(\mathrm{III}), \mathrm{DBO}, \mathrm{DQO}$, sólidos totais, e cations e ânions maiores.

\section{Introdução}

Em todo o mundo, a existência de áreas contaminadas, têm se transformado num dos mais graves problemas ambientais com que os governos têm que lidar, uma vez que as deposições de resíduos industriais e do lixo urbano, quase sempre, não obedecem as normas devidas de proteção dos recursos naturais.

A disposição de resíduos deve ser considerada como fonte potencial de contaminação, mesmo aquelas nas quais tenham sido implantadas medidas que proporcionam maior segurança à unidade, como camadas basais impermeabilizantes, drenos, e lagoas de depuração, etc. A ocorrência de contaminação de solos e águas subterrâneas tem sido associada a muitos dos depósitos de lixo existentes no mundo, inclusive aqueles considerados seguros (CETESB, 2001).

No município de Alagoinhas, BA, o despejo dos resíduos sólidos urbanos está, atualmente, sendo feito em um aterro sanitário. Contudo, antes da construção do mesmo, os resíduos produzidos pelo município eram depositados a céu aberto, num lixão localizado no mesmo local entre o atual aterro e o curtume da empresa BRESPEL (Fig. 1).

Este estudo está sendo realizado no contexto de um plano de saneamento para Alagoinhas proposto pela Escola Politécnica da UFBA através de um convênio estabelecido com a prefeitura municipal. O principal objetivo do trabalho envolveu o conhecimento da geologia de sub-superfície da área no entorno do novo aterro, do lixão desativado e do curtume da BRESPEL. Além disso, pretendeu-se caracterizar as eventuais contaminações provocadas por materiais ali depositados ou manipulados. Para tanto, utilizou-se metodologia 'screening', em conformidade com o Manual de Gerenciamento de Áreas Contaminadas da CETESB (CETESB, 2001), com a realização de uma investigação geofísica com eletrorresistividade e análises físicoquímicas e bacteriológicas das águas subterrâneas e superficiais.

Quarenta e nove sondagens elétricas foram executadas com o objetivo de delimitar os aqüíferos até profundidades da ordem de $100 \mathrm{~m}$, assim como efetuar imageamentos de uma contaminação da água subterrânea (posição e frente de pluma contaminante). Esses resultados permitiram também determinar a profundidade do nível estático (topo da zona saturada) e as principais direções do fluxo hidráulico no subsolo. Os dados geofísicos também possibilitaram delinear a extensão e espessura da camada de material acumulada no lixão. Análises físico-químicas e bacteriológicas de sete amostras de águas superficiais e subterrâneas, coletadas em pontos selecionados, confirmam a modelagem descrita.

\section{Metodologia}

A metodologia empregada teve como base às normas da CETESB (2001) que incluem instrumentos para investigação confirmatória de contaminação em uma determinada área. Uma avaliação preliminar foi efetuada na forma de um diagnóstico baseado na análise de informações disponíveis sobre cada uma das áreas identificadas e o reconhecimento das mesmas através de inspeções de campo. Para tal a ficha cadastral de área contaminada utilizada em São Paulo serviu de guia. Um modelo conceitual de contaminação constituiu a síntese das informações obtidas, descritas adiante na caracterização da área de estudo.

A confirmação da contaminação na área foi feita basicamente pela utilização da metodologia 'screening (reconhecimento e rastreamento), com o emprego de sondagens geofísicas e análises físico-químicas de águas. Após esta etapa foi definida a continuidade dos estudos para obtenção de dados analíticos para uma futura caracterização detalhada do local afetado e para orientar planos de monitoramento e de recuperação da área alterada. A investigação geofísica foi realizada no período de janeiro a fevereiro de 2004, e consistiu da execução de 41 sondagens elétricas verticais rasas (até $A B / 2$ máximo de $200 \mathrm{~m}$ ) e 8 sondagens mais profundas ( $A B / 2$ máximo de $800 m)$, seletivamente centradas sobre 
as áreas do aterro sanitário, do antigo lixão, e da planta industrial da BRESPEL (Fig. 1).

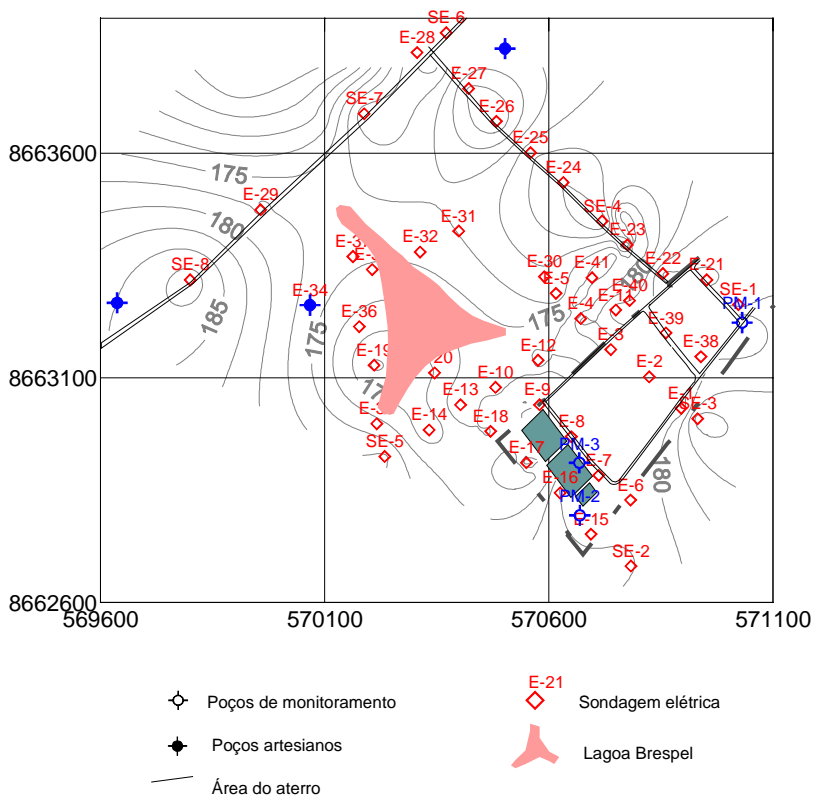

Figura 1 - Mapa de localização das SEVs na área.

Amostras de águas subterrânea e superficial foram coletadas num poço produtor localizado na fazenda contígua ao aterro (P-1), nos poços de monitoramento do aterro (P-2 e P-3) e no poço produtor do curtume (P-4). Outros pontos de coleta incluíram águas do rio Sauípe e afluente, antes da saída do efluente do curtume (p5), na saída do efluente (p6) e a jusante deste ponto (p7). A interpretação dos resultados foi feita por comparação dos valores de concentração obtidos com padrões definidos na Resolução 20/86 do CONAMA e na portaria 518/04 do Ministério da Saúde, usando ainda dados obtidos num estudo realizado no rio Sauípe pela SRH (Plano Diretor de Bacias Hidrográficas $-\mathrm{SRH}, 1995)$.

\section{Resultados}

A área de estudo situa-se na confluência da rodovia BR $101 \mathrm{com}$ a via de ligação ao distrito de Rio Branco (Fig. 1). Além das áreas do curtume, do antigo lixão e do atual aterro sanitário, a região inclui ainda as seguintes atividades de riscos de contaminação de solos e águas: (i) a existência de um poço de exploração petrolífera da PETROBRAS, no momento desativado; (ii) a presença de um auto-posto de serviços para veículos pesados; e (iii) a existência de extensas zonas reflorestadas com eucaliptos.

Do ponto de vista geológico a área inclui depósitos das formações Barreiras e Marizal repousando, em discordância erosiva, sobre uma espessa seqüência dominantemente arenosa da Formação São Sebastião.
Em afloramentos, observa-se que tanto a Formação Marizal quanto a Formação Barreiras, são constituídas de arenitos pouco argilosos com raras e finas camadas de folhelhos.

O aterro e o lixão situam-se numa vertente suave do terreno, com inclinação de sul para norte. Neles o material terrígeno de recobrimento não foi adequado para isolar os resíduos, sendo facilmente erodível pelas águas pluviais. Isso deixa o lixo exposto a ação de catadores e urubus. A impermeabilização de argila na base do aterro também não garante longevidade à proteção do subsolo. $\mathrm{Na}$ confluência de duas drenagens afluentes do Sauípe, encontram-se as lagoas de disposição dos resíduos do curtume (Fig. 1). Estas não possuem impermeabilização basais adequadas, embora estejam sendo parcialmente aterradas como parte de um processo de recomposição ambiental em execução pela BRESPEL.

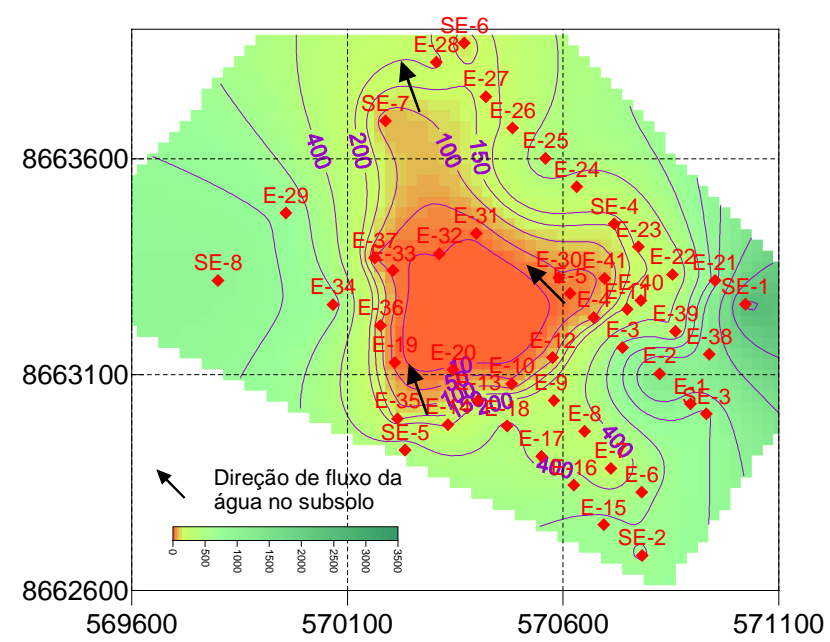

Figura 2 - Mapa da função resistividade aparente para $A B / 2$ de $100 m$.

Os principais insumos utilizados na BRESPEL são cloreto e sulfeto de sódio, óxido de cálcio, sulfato de cromo, e anilinas. O sulfeto de sódio e o cromo são reciclados, em sua maior parte, sendo o excedente lançado nas lagoas. O sal marinho residual é levado ao aterro sanitário e os demais resíduos compõem o efluente que é lançado em lagoas de estabilização.

A figura 1 mostra a distribuição dos centros das SEVs com designações SE para as sondagens profundas e E para as sondagens rasas. No campo foram utilizados arranjos Schlumberger de eletrodos e o sistema elétrico SYSCAL R-2 do CPGG/UFBA. Os resultados das 49 sondagens elétricas foram quantitativamente interpretados e representados na forma de mapas e seções geoelétricas.

A figura 2 contém um mapa da função resistividade aparente medida para espaçamento de eletrodos $A B / 2$ de $100 m$. Ele delineia, em sub-superfície, 
uma forte anomalia condutora ( $\rho_{a} \leq 10$ Ohm.m), lateralmente limitada e que se estende da parte ocidental do aterro até o rio Sauípe. Esta anomalia se insere num 'background regional resistivo ( $\left.\rho_{a} \geq 600 \mathrm{Ohm} . \mathrm{m}\right)$, valor característico de arenitos limpos saturados com águas doces. Mapas similares foram construídos para $\rho_{a}$ medidos com $A B / 2$ de 10,50 e $200 m$ e registram o mesmo corpo anômalo, delimitado entre as profundidades de 5 e $50 \mathrm{~m}$.

$\mathrm{Na}$ figura 3 estão alguns exemplos de curvas de sondagens obtidas na área. As sondagens SE-1 e SE-8 refletem a sucessão litológica regional observada sob condições normais de saturação. A presença de um substrato condutor é revelada, abaixo da profundidade de $80 \mathrm{~m}$, sendo atribuído a extensos folhelhos da Formação São Sebastião. A sondagem SE-4, todavia, já mostra efeitos de um intervalo condutor mais raso, interpretado como resultante de alterações de qualidade na água do aqüífero.

Um mapa da distribuição da resistividade verdadeira do aqüífero, imediatamente abaixo do nível freático, é mostrado na figura 4. Com ele é possível demarcar a extensão lateral e a intensidade da pluma de contaminação. Supondo matriz arenosa limpa é possível inferir que a salinidade da água na zona condutora é ampliada por um fator de quase 100 com respeito a salinidade normal da água subterrânea.

\section{Discussão e Conclusões}

Os dados de resistividade verdadeira das unidades geoelétricas em sub-superfície delineiam uma expressiva anomalia de forte contraste material. Esta pode tanto resultar de uma variação faciológica em termos de argilosidade por exemplo, quanto de uma alteração radical na qualidade do fluido intersticial. A associação direta da anomalia com áreas de despejos superficiais e os dados físico-químicos das águas nos levam a supor que a mesma esteja relacionada com uma contaminação provocada pelo pacote de resíduos do lixão e pelas lagoas residuais do curtume.

Em profundidade a pluma parece se caracterizar por um núcleo central mais concentrado envolvido por uma aureola de transição. Esta mancha parece flutuar de modo instável (como um processo dinâmico) sobre águas doces abaixo de uma profundidade de cerca de $40 \mathrm{~m}$. A expansão mais homogênea desta pluma se concentra sob a área do antigo lixão e sob as lagoas de rejeito do curtume, onde a resistividade da zona saturada alcança valores inferiores a 10 Ohm.m.

Os resultados das análises químicas apontam para existência de contaminação nas águas superficiais. O rio Sauípe e seu afluente recebem o efluente do curtume praticamente sem tratamento e os sinais de poluição são visíveis pela cor das águas e pelos odores desagradáveis. Há alterações também na dureza total, DBO, DQO, sólidos suspensos e dissolvidos, nutrientes, cátions, ânions e $\mathrm{Cr}(\mathrm{III})$.
As altas concentrações de DBO e DQO nos pontos p6 e p7 apontam para uma depleção do oxigênio dissolvido resultante da demanda elevada para os processos microbiológicos de oxidação do excesso de matéria orgânica presente na água. Estes parâmetros avaliados conjuntamente com os teores dos nutrientes nitrogênio e fósforo, revelam processo de eutrofização das águas do rio, fato este também circunstanciado pelas condições de barramento e alteração do fluxo normal ao qual foi submetido.

A concentração de cromo trivalente nos pontos 6 e 7 caracteriza a contaminação promovida pela descarga de efluentes do curtume. O curtimento do couro utilizando - cromo é hoje o principal método aplicado para estabilizar as fibras de colágeno da pele animal.

Observa-se que as amostras recolhidas nos poços apresentam sem exceção sólidos em suspensão em concentrações consideradas elevadas para águas subterrâneas, principalmente o poço 2 localizado no aterro sanitário. O poço 4 , utilizado para abastecimento público, apresenta sólidos dissolvidos dentro dos padrões estabelecidos pela portaria 518/2004 do Ministério da Saúde para água potável.

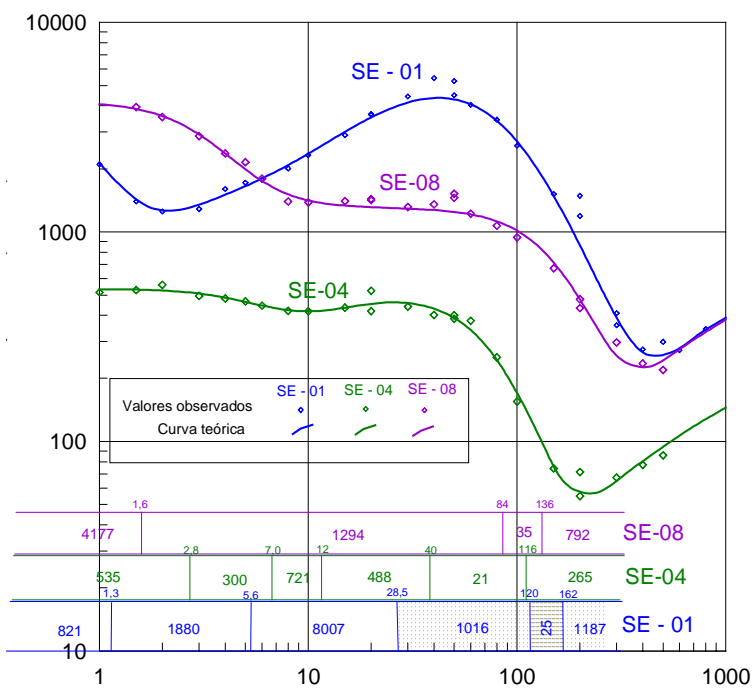

Figura 3 - Curvas de sondagens elétricas representativas da área.

\section{Agradecimentos}

Os autores agradecem a Prefeitura Municipal de Alagoinhas e a Petrobras pelo apoio a realização do presente trabalho, ao CPGG/UFBA pelo ambiente e suporte ao projeto e ao CNPq pelo financiamento de bolsas de pesquisa. 


\section{Referências}

BRASIL. Resolução CONAMA nำ 20, de 18 de junho de 1986. Estabelece a classificação das águas, doces, salobras, e salinas do Território Nacional.Diário Oficial da União, Brasília, DF, 30 de julho de 1986. Disponível em: http://www.mma.gov.br

BRASIL. Portaria $n^{\circ}$ 518, de 25 de março de 2004. Estabelece os procedimentos e responsabilidades relativos ao controle e vigilância da qualidade da água para consumo humano e seu padrão de potabilidade, e dá outras providências. Disponível em: http://www. ms.gov.br

BAHIA. Plano Diretor de Recursos Hídricos. Bacia do rio Sauípe. Disponível em: http://www.cra.ba.gov.br.

CETESB. Manual de gerenciamento de áreas contaminadas. São Paulo: CETESB. CETESB, GTZ. 2.ed 389p. 2001.

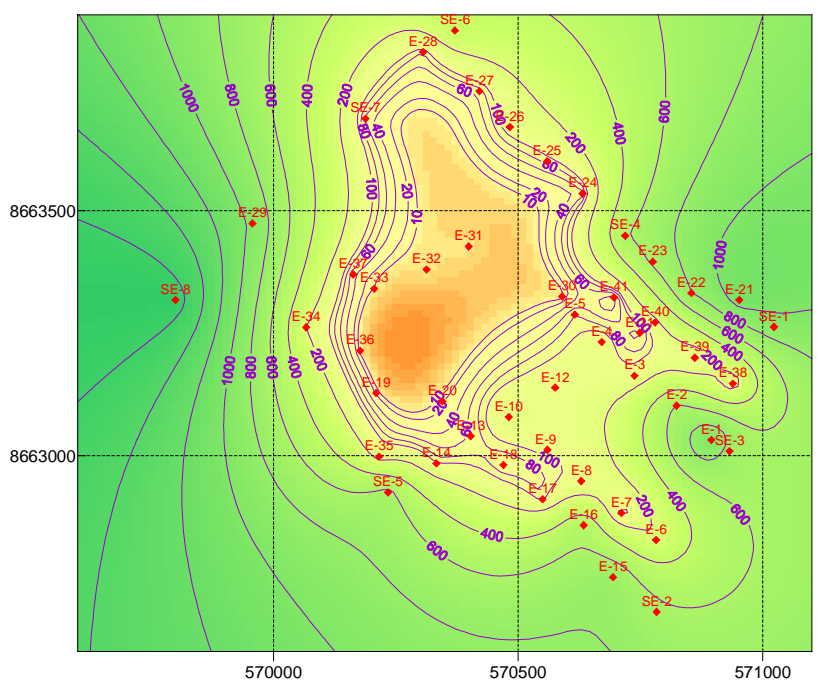

Figura 4 - Mapa da resistividade verdadeira do aqüífero interpretada das SEVs. 